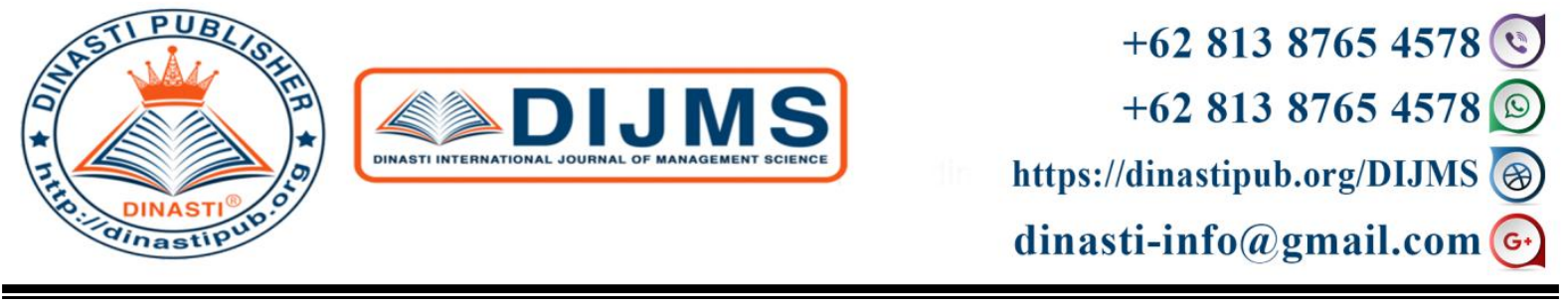

\title{
THE STRUGGLE OF HUMAN RIGHTS DIPLOMACY OF INDONESIAN COUNTRY CITIZENS DEATH PENALTY
}

\section{Patricia Robin}

Universitas Bunda Mulia, Tangerang, Indonesia

\begin{tabular}{|l|l|}
\hline ARTICLE INFORMATION & $\begin{array}{l}\text { Abstract: The ability of politics and diplomacy } \\
\text { Received: } 19^{\text {th }} \text { April } 2020 \\
\text { Revised: } 25^{\text {th }} \text { April } 2020 \\
\text { Issued: } 08^{\text {th }} \text { May } 2020 \\
\text { The problem when human rights come against the law, } \\
\text { will lead to a tendency to be take the side of the law, as } \\
\text { opposed to giving unpleasant things to those who make } \\
\text { mistakes. This not infrequently results in the death } \\
\text { Patricia }\end{array}$ \\
$\begin{array}{l}\text { E-mail: } \\
\text { patrobin23@gmail.com which eventually (again) contradicts the } \\
\text { Human Right to live properly and in protection. This } \\
\text { condition occurs in migrant workers who work in } \\
\text { several countries in Asia. They were accused of } \\
\text { mistakes that incidentally have not been proven but } \\
\text { immediately get a death sentence. The best national } \\
\text { ambassadors were assigned to conflict areas, } \\
\text { succeeded in the mission of saving them. Consistency, } \\
\text { innovation, and enrichment when diplomacy is } \\
\text { equipped with the ability to read the situation is the } \\
\text { key to the success of diplomats when rescuing. } \\
\text { Indonesia's ability to maintain good relations with } \\
\text { other countries finally deserves to be regarded as the } \\
\text { peak of achievement. } \\
\text { Keywords: Law, Human Rights, Women in Politics, } \\
\text { Silent Diplomacy, Art of Persuasion }\end{array}$ \\
\hline
\end{tabular}

\section{INTRODUCTION}

The existence of Indonesia in the eyes of the world is increasingly seen and felt, with various actions in terms of economy, business, tourism, law, and politics. One determining factor is Indonesia's ability to manage the aspects of government, policy and state governance. So no doubt, communication then becomes the key. The existence of communication as a practice, easily accepted by the general public. However, there are doubts about how the actual relationship of communication relating to other branches of science? Does daily communication play an important role in international implementation? 
This is interesting to discuss, especially in his debate with the politics and laws that apply, and should not be forgotten, anyone (communicator and communicant) involved in it.

Politics is increasingly interesting to be discussed by people from various backgrounds and social classes with different intensity and different perceptions. The presence of political regimes with a certain character and performance strengthens each human's perception of the political world. Some think that politics is synonymous with manipulation, fraud, and crime. However, who think about politics with the struggle for shared values and public interests for the sake of victory in the history of human life (Ahmad, 2012: 42).

Political communication is a communication process that has implications or participation in political activities. Indonesia as one of the countries that adhere to the democratic system also practices political communication in its various activities at home and abroad. One of these compilations is to activate the state's protection function in protecting the rights of Indonesian citizens in other countries.

The practice that cannot be separated from political communication is diplomacy. The purpose of diplomacy is an agreement policy that can produce results and give benefit for both parties. In the discussion of this paper, it will be explained in full related to the diplomacy carried out by diplomats in saving their lives and fighting for Human Rights (Hak Asasi Manusia - HAM) in a country that gives a death sentence for Indonesian citizens (Warga Negara Indonesia). This punishment seemed to be a common punishment accepted by the world, but Indonesia dared to take a stand to succeed and alleviate its disappearance in a heinous way.

From the data presented at the Ministry of Foreign Affairs, in the period 2014 - 2019, Indonesia succeeded in resolving 73,503 cases, saving 297 Indonesian citizens from guaranteeing the death penalty; 574 billion financial rights of Indonesian citizens / PMI successfully rescued and 43 Indonesian citizens successfully rescued from being held hostage (https://kemlu.go.id/portal/id/read/582/view/menlu-retno-dorong-pemb formation-service system-and- standardized and integrated protection).

The murder case became the first rank that caused Indonesian citizens to refuse to die in the country where he was. Followed by the second rank of things that are not owned, followed by related to drugs, adultery for the use of magic and possession of firearms. The diverse and unclassified causes of the death penalty convince the writer who proves that diplomacy used by the Ministry of Foreign Affairs is so maximal (https://beritagar.id/artikel/berita/pemerintah-klaim-sel Salvation-ratusan-wni-dari-hukummati ).

Various disputes with various characteristics of the state can be dammed. So, inviting the leader, the Minister of Foreign Affairs, Retno L. Marsudi, was interesting to discuss. Not without reason, being the first female foreign minister in Indonesia, her success in the world scene is not in doubt. Various achievements he made, ranging from personal relationships (also as the first woman to be received by the Indonesian ambassador to the Netherlands), received a Merit Certificate as the "Best Ambassador" from the prestigious diplomatic magazine Diplomat Magazine in 2015. Retno LP Marsudi also delivered Indonesia as Non- 
Permanent Members of the UN Security Council 2019-2020, along with the re-election of Indonesia as a member of the UN Human Rights Council 2020-2022 Period. Retno LP Marsudi is a woman with extraordinary actions in the political arena, making her stunning Indonesia and the world (https: / /www.antaranews.com/berita/1127264/profil-menlu-retnomarsudi-diplomat-ulung-segudang-prestasi).

The Indonesian state does not provide training or early counseling for Indonesian citizens who will try their fortune abroad, the next step being homework that must be encouraged. The same is true of what Indonesia has provided in good relations with the giving country.

\section{LITERATURE REVIEW}

The discussion on the struggle for human rights diplomacy of Indonesian citizens sentenced to death put forward the diplomatic elements of diplomatic tactics in making joint agreements with prospective executor countries. Their ability is not formed from ease or a short time, but rather a long journey after understanding also the fundamental existence of politics that makes it easier when moving.

Politics is fundamental; An unlimited activity, usually associated with public institutions that care about the processes and practices of government, and policymaking. On the other hand, it has universal and broad aspects of human behavior and can be found among at least two individuals involved in formal or informal, public or private collective activities.

If foreign policy is the name for the process, then the effective tool through that process is diplomacy which is the key when collective political activity, in relation, is no longer between individuals, but between countries.

Diplomacy is used as a method of achieving conformity and reconciling differences in foreign policy objectives between countries. Karl W. Deutsch defines diplomacy as the art of negotiating between governments that are not coercive with one another. In the view of expert Ellis Briggs, diplomacy is no different from the official activities of trained personnel who represent the government and aim at reaching international scope agreement.

Not alone, diplomacy is required to have certain elements, including negotiation, which is an act of realizing shared values between each party; Diplomacy is a national interest, so it must be distinguished from personal interests; In diplomacy, as much as possible is done peacefully; Diplomatic techniques must be based on the awareness of the worst possibilities, namely war; Diplomacy is related to a country's foreign policy, so it is often related to the country's domestic issues; Diplomacy related to the state system; And finally, diplomatic representation is a representation of a country (Dinh, 1987).

The figure who holds an important role is a diplomat. The task of a diplomat is to provide information to the government about the events of the country in which he is placed, while on the other hand, explain the state's policies to other governments to fulfill the country's goals (Roy, 1995)

The ability of a diplomat is inseparable from his ability to build a good image and qualified techniques of persuasion. One reasonable and feasible way to use is to build the credibility of the actor or diplomat himself. This relates to developing competencies that are 
expected to make the communicant accept and appreciate the communicator's intellectual, experience and knowledge; and character development, which helps show sincerity, care, and trust built from a communicator (Lucas, 2012: 356).

Actors (diplomats) need to be careful in finding ways to strengthen their positions, as well as determining the negotiation settlement styles needed. The constructive process involving hard-line elements must also be considered to get the best tactics in achieving goals. Not all decision making is based on value maximization or just a cost-benefit analysis. Another key dimension is ensuring the strategy is based on a good understanding of the dynamics of the community or the location where the practice of diplomacy is carried out. This requires anticipation of how policy sanctions and incentives will be interpreted by various social constituencies (Griffith, 2008).

The task of diplomats is not far from the dialogue that is appropriate for use even during conflicts. The important thing to remember is that negotiations towards conflict resolution almost always need to be preceded by informal dialogue. Casual dialogue is exploratory and non-commitment often shows progress rather than seeking commitment. The existence of low profile dialogue is more likely to succeed than merely being in the international spotlight. The last factor is a matter of time that continues to run. Become more leverage when time is spent talking with your enemy, rather than chatting casually (Griffith, 2008).

In the past, the main issue raised in diplomacy was trading. This has been going on since the time of bilateral diplomacy between two kingdoms or countries because of the economic nature which states that the state is unable to meet all needs independently. Furthermore, in the multilateral period, trading system was increasingly complicated so that it needed negotiations for domestic and international interests (Nicolaidis, 1996: 1).

Times change, the needs of the country rise to the realm of recognition and existence. This brings new challenges when interacting. The mission promotes cultural grandeur and introduces the people of other countries to the culture taking part. Cultural diplomacy also builds intimacy between nations (Roy, 1998: 12).

These two issues are motivated by world attention on human rights. There is a declaration prepared by the United Nations, ECOSOC (Commission on Human Rights of the Economic and Social Council), namely the Universal Declaration of Human Rights which discusses freedom. This is a concern of the world after the genocide of World Wars I and II. Socio-cultural and economic problems in international relations originated from this concern for human rights, including the role of non-state actors such as corporations and associations (Redmand, 2008).

There are several types of diplomacy carried out by countries when interacting. Starting from the old diplomacy style that was carried out from 1500 to World War I; secret diplomacy is a form of secret diplomacy forever unnoticed by the people, or Public Diplomacy as a government effort against the public itself and the international community to improve their image. The case of the liberation of human rights of Indonesian citizens sentenced to death in other countries uses the tactic of silent diplomacy (i.e. quiet diplomacy) which is deliberately carried out without publication to such a stage, so that when it is felt 
safe in reaching an agreement, then this matter is published. This was done so that domestic public opinion did not spread until finally frustrating the government's plans. This tactic was also used by President Soeharto when normalizing diplomatic relations with the Deputy Government of China.

The next discussion is about what diplomats fight for. Human rights is the main root that is put forward. In the Law of the Republic of Indonesia Number 39 of 1999 concerning Human Rights, the human rights highlighted by the author, in this case, are in Article 7 paragraph 2, namely the provisions of international law that have been accepted by the Republic of Indonesia regarding human rights, mainly the responsibility of the Government; and also Article 33, namely that every person has the right to be free from enforced disappearances.

Referring to the Act and its compatibility with the realm of diplomacy, human rights are worthy of being championed by diplomats. N.A. Maryan Green in the International Law of Peace stated the functions of diplomats include Representing the government; Reporting what happens in the country based on observations and work done; Negotiating such as attending international meetings; Promoting the economic, cultural and others; and the last is Protecting citizens in the countries. The struggle for human rights in this matter is in the 5th (and so significant) diplomacy function (https://www.komnasham.go.id/files/1475231474-uunomor-39-tahun-1999-about-\$H9FVDS. pdf).

Furthermore, the figure of women who used to be rarely in government circles is now beginning to shift and have an increasingly public and recognized role. This is nothing but progress because women can enjoy the same educational opportunities as men. Now many women sit in parliament (compared to the previous period) because the Government of Indonesia is also committed to upholding women's rights through various legal regulations. Gender equality is one of the international commitments and conventions. What is expected is to make Indonesia a class because, in 2007, Indonesia ranked 80th out of 156 countries in the Gender Development Index and ranked 90th in 2009 (UNDP, 2010: 1).

The next presentment that is important to discuss is the figure of women in politics. In carrying out its functions in the cabinet, there are discursive and ideological challenges. One of them is a role that is not recognized socially so that fewer resources are invested in women as a capital (human capital) by both family and state. The problem of the public sphere comes precisely from the vast territorial separation between the public and private spheres. The ideology of separating labor by sex determines women as private citizens with roles as mother and wife; while on the other hand, men are given productive roles in the public sphere (UNDP, 2010: 21).

The social context is slowly changing and supporting women's participation in the public sphere. Polls and surveys show respondents support gender quotas for women in the political and government sectors. More than half of respondents also showed a desire to see women in decision-making positions in government. This is a trend of positive social trends, thus providing opportunities for women to politicize and hold important positions (UNDP, 2010: 26). 
Connecting between diplomats and women politicians is interesting. The government must be responsible for the results of gender equality and institutional reform priorities including the provision of new structures of regulations and procedures, performance criteria, monitoring and evaluation, current promotion and accountability mechanisms from a gender perspective (UNDP, 2010: 35).

The diplomat is in charge of a mouthpiece to other countries to achieve foreign political interests. Presented by Foreign Minister Retno LP Marsudi, seen so far that the figure of a diplomat is a person who appears in the mass media or various state events with so "beautiful" and credible. Behind it all, the task of a diplomat is not easy to let alone a little.

Many lives of citizens themselves must be accounted for, let alone enter a country full of conflict and polemics.

\section{RESEARCH METHODS}

Discussion about the struggle for human rights diplomacy of Indonesian citizens in neighboring countries is interesting to be made in a form of research because it contains several elements in it. The author can not let go of the elements of communication, women in the world of politics, diplomacy, and persuasion.

In dissecting this phenomenon, the author focuses on the methodology that will be used, namely the use of qualitative research methods that use multiple methods in terms of research focus, which involves the process of interpreting the subject's natural conditions. Qualitative research emphasizes the reality or facts of the social construct, the closeness of the relationship between the researcher and the problem under study, and the situation that compels the study. So, it can be said that this research seeks answers from how social experience is created and gives meaning (Denzin \& Lincoln, 1994).

Bogdan defines that this method appears as a research procedure that produces descriptive data in the form of written or oral words of the object whose behavior is observed. This approach is directed at the background of individuals who are whole or holistically, which essentially views the individual as a whole, not into variables or hypotheses (Moleong, 2007: 4).

Things that should not be released when making or compiling research is about the paradigm that will help in answering what must be learned, the problems that must be answered, the proper way and must when answering it until the proper rules are followed. The author uses a constructivist paradigm related to cognitive development theory. In this case, the authors play an active role in building their understanding of the knowledge learned. According to Anderson, in the view of constructivism, individuals are seen as constructing knowledge on an ongoing basis, assimilating and accommodating new information to produce various understandings of reconstruction candidates, in which the traditional positivist criteria for internal and external validity are replaced with terms of trustworthiness and authenticity.

Politics is the first word that according to the author is relevant to research. A political journey like that cannot be denied must be carried out by every country, both it's a relationship with politics at home and abroad. Robert E.Gordin and Hans-Dieter Klingemann 
(1996: 7) explained that politics is limited use of social power. Social power is based on the existence of a power that is present in social (and state) life.

More specific politics here is foreign policy, which means the process of assessment and identification of the ability of the State to achieve interests. One term that is familiarly known as a national power, which is the power of a nation to interact with other countries. This is connected with the national interest, namely the interests of the State in achieving certain goals, such as freedom, security, and even independence. This is liquid and worth fighting for because it involves the livelihood of the community. There is no equalization and standardization of national interest from each country, due to different conditions (Wardhani, 2015).

The existence of two countries experiences maximum interaction. What's confusing is when the two countries have different understandings of the implementation of the law. Which one should be followed if there is a violation? But in the name of human rights and the agreed Vienna Convention, the two countries are carrying out so-called diplomatic practices.

The key figure who plays a role in the journey of diplomacy is the diplomat. Serving as a mouthpiece to other countries to achieve foreign political interests, diplomats carry a minimum of 5 tasks such as Representing, Reporting, Negotiating Promoting, and Protecting. This is a form of fundamental work that must be done and does not stop there, there are many more that must be done by diplomats who aim to maintain the existence and image of the country in other countries.

Presented by Foreign Minister Retno LP Marsudi, seen so far that the figure of a diplomat is a person who appears in the mass media or various state events with so "beautiful" and credible. Behind it all, the task of a diplomat is not easy to let alone a little. Many lives of citizens themselves must be accounted for, let alone enter a country full of conflict and polemics

This research focuses on the success of diplomats in carrying out their functions, namely fighting for the human rights of citizens who receive unfair treatment. Communication skills are the basis, persuasion is the key. But what should not be forgotten is the existence of state support until the time of liberation.

\section{RESULTS AND DISCUSSION}

Indonesia is classified as a rich country. The definition of rich here is not merely about a capable financial capacity, supported also "rich" in terms of Natural Resources or Human Resources. When discussing the location of Indonesia that intersects with other countries, special and strategic positions can be requested. It is bordered by Malaysia, Singapore, and the Philippines on the north side; Australia on the south side; The Indian Ocean on the west side; and Papua New Guinea on the east side, making Indonesia also has diverse bilateral cooperation with these countries.

Curiosity wrote about How the appeal of the neighboring countries that "invite" Indonesian workers to work there was answered fundamentally with the relationship between Indonesia and Malaysia. The two heads of state are known as figures who are familiar with each other lying down. Prime Minister Mahathir Mohamad and President Joko Widodo have 
a fairly close personal relationship with relatives. Not just from an acquaintance, but the intention to be brothers until whenever more often echoed.

These fellow Malay families most often "hear" have news with Indonesia. The news then becomes a form between two things, "love and hatred" - love and hate relationships. This does not apply once, it needs to be very often. Call it the sports sector, the economy, claims and business comments, culture, politics, to citizens' social issues.

Regarding these interrelating factors, the discussion about social issues about Indonesian Workers (TKI - migrant workers) working in the neighboring country is the most interesting. The National Agency for the Placement and Protection of Indonesian Workers (BNP2TKI) recorded the number of migrant workers in various countries was 283,640 workers with a combination of $47 \%$ workers in the formal sector and $53 \%$ in the informal sector. Malaysia is the main destination country for Indonesian Migrant Workers, reaching 90,671 workers or almost one-third of the total number of Indonesian Migrant Workers. (https://databoks.katadata.co.id/datapublish/2019/04/09/malaysia-masih-jadi-targets-utamapara- Indonesian workers).

Those who are willing to try their luck and fortune their fortune in Malaysia, are truly fortunate in their work, but they face difficulties to get a job and a decent life if they try their fortune in Indonesia. This becomes a scandal for the Government, when the sons and daughters of the nation choose to provide the capabilities and skills possessed in their own country. What is wrong here? Does this show that the government has failed to create jobs?

From the writer's point of view, it was stated that this was not the cause. From several sources that were adapted, interpersonal communication and the ability of migrant workers who had worked in neighboring countries seemed to be a separate magnet for those who wanted to feel living and becoming a Foreign Citizen. Workers who have previously been to Malaysia have a greater effect on the psychology of potential foreign exchange- earners. Many of them heard the story that they could get a large salary if they worked abroad (after being converted and given to families in Indonesia). Finally, they were willing to challenge work in Malaysia. But it turns out that there are lots of dealers who are bulging, just giving up wishful thinking, without ever being real.

The knowledge of these men and women is broad, but only touches the surface of the fraction of suffering and torture that they are likely to receive. What is not remembered by the prospective workers, it is a story of someone who means the element of subjectivity is so high. It is very strange but true when those who know Malaysia is identical to human trafficking or violence that leads to death, still giving up their young or old days to be able to work there. Even those who have felt that they are victims of trafficking still want to return to work, if approved by their parents.

This does not mean that they are not seen by the government or those in authority there. Intercountry meetings continue to take place at different locations and times. The Malaysian Prime Minister often voiced the need to increase cooperation between the two countries in a variety of sectors that began with the policy or the basis of relations between the two "intimate" countries. But like giving a one-sided view of the issue of human rights, law and migrant workers, which is quite widespread, when the two leaders of the country meet, Human Resources and policies which if important are discussed as if vanished. 
Discussions that are suaver in nature such as good governance, state management, intentions to fight corruption, border issues, and defense and security seem to be sexier.

Discussions also discussed at the bilateral meeting were trade and business relations. The two countries agreed to increase investment between countries and strengthen cooperation in the strategic economic sector. The trade war that took place in the world is not a place for Malaysia and Indonesia to fight, but it is more like being together to find a solution. Again, cultural and historical similarities, which are used as a basis for understanding the business landscape in both countries when increasing investment.

Apart from some of the ideals and realities presented by Indonesia and Malaysia, some ideals are closely related to the present, namely to humiliate the relations of the people of the two countries. It is a common goal that 264 million Indonesians and 32 million Malaysians can unite and interact politely, especially in the world of social media. Not easily provoked by each other mainly just because of a small matter.

Furthermore, the issue of humanity which was slightly flicked by the bilateral meeting of the two countries on humanity was to strengthen military cooperation and the security forces of the two countries. This was initiated by an increasingly disquieting world situation when it had to face global challenges and crimes ranging from terrorism to drug trafficking and people.

Looking at the issues that are circulating at a macro level, the government at the top level does not seem to care about the existence of these workers, it is not the case at all. They feel like trying to determine the best policy that does not harm any party. Such tactics are also in line with the authority of the Ministry of Foreign Affairs as a regulatory body as well as filtering the existence of migrant workers.

Judging from the requirements when submitting themselves as a figure of prospective migrant workers, the requirements provided are also not small. Just mention the obligation to have a valid passport, a qualified age of 18 - 45 years, as well as the certainty that it is legal to come to Malaysia through the Government or Private TKI Placement Implementing Company (PPTKIS-first PJTKI) registered with the Republic of Indonesia Ministry of Manpower.

Discussed above how those who try their fortune abroad mean having the opportunity to have large amounts of money. There is still capital they have to give in the form of money and time. They are also obliged to report their presence in Malaysia to the Indonesian Representative in Malaysia. This is intended so that RI Representatives can provide assistance and protection to Indonesian citizens in case of problems. Besides that, an Indonesian citizen can lose his citizenship if he does not report his existence to the Indonesian Representative for 5 consecutive years (https://kemlu.go.id/kualalumpur/id/pages /bhow_menjadi_tenaga_kerja_indonesia/97/about- service).

Discuss the conditions, procedures, and policies that exist in the practice of migrant workers to other countries. The case became the main essence conical to the understanding that was raised by the author as an extraordinarily important issue to be discussed. This is about human rights and protection in law. 
This refers to UU REPUBLIK INDONESIA NOMOR 39 TAHUN 1999 TENTANG HAK ASASI MANUSIA yaitu Pasal 7 ayat 2, yang berbunyi :

"Ketentuan hukum internasional yang telah diterima negara Republik Indonesia yang menyangkut hak asasi manusia terutama menjadi tanggung jawab Pemerintah"

The author analyzes that wherever an Indonesian citizen is, he is entitled to protection. Following the rules and laws of the country where the incident took place is not wrong. But proper and maximum legal assistance from the Indonesian state is also felt to be an obligation. It would be very troubling if the suspect or suspected perpetrator fight for his rights without being accompanied by a country which is already beneath like a parent who sent, allowed or at least knew the "child" to try his luck in a foreign country.

By this analogy of parent and child, the writer assures that pasal 33 ayat 2 can be implemented well. The article reads: "Setiap orang berhak untuk bebas dari penghilangan paksa dan penghilangan nyawa."

Human rights become a fixed price that is upheld by the Indonesian state. Regarding the phenomena that occur and the main focus of the authors in this study is the death sentence, it becomes very naive if the state easily leaves its people. There are certainly many Indonesian workers who try their fortune in overseas countries, but the existence of lives cannot be replaced just like that.

The more reference and discussion of human rights, law, and politics, the existence of Indonesia among other countries in Asia and the world, the more interesting and unimaginable the role of diplomacy is. The diplomacy owned by Minister of Foreign Affairs Retno LP Marsudi need not be doubted because he can always be number one or first.

Being the first female ambassador in the Netherlands, as well as being the first female Foreign Minister in Indonesia, brought the name Retno to be considered by the world. She also made an important contribution when Indonesia discussed the regulations regarding migrant workers relating to Saudi Arabia. Some memorandum of agreement that was produced by him when he received the visit of Minister Al-Jubeir, among others, welcomed the commitment of the Saudi Arabian government to continue to improve the protection of Indonesian workers, especially related to working hours, minimum wages, and respect for workers' rights. Retno LP Marsudi also requested the realization of consular notification cooperation which was so commonplace by following the Vienna Convention.

Through this consular notification, the Embassy of Indonesia Republic (KBRI) in the Capital City of Riyadh and the Consulate General of the Republic of Indonesia (KJRI) in the City of Jeddah can optimally protect Indonesian citizens in Saudi Arabia which impact on increasing cooperation in fighting for peace, tolerance and peaceful resolution of conflicts.

Retno LP Marsudi's ability to negotiate and actual diplomacy is complemented by the success of the Ministry of Manpower to make a bilateral agreement on the creation of a single channel migrant workers system that was formalized in October 2018. This cooperation is in the framework of protecting the rights of migrant workers and regulating employment relations between employers and workers migrants comply with laws and regulations in both countries and international conventions. 
The success of Retno LP Marsudi in establishing good relations with Saudi Arabia seems to be truly fruitful. The Minister's success was followed by the success of his subordinates who provided the best service in the land of that person. The Indonesian ambassador to the Saudi, Agus Maftuh Abegebriel, succeeded in freeing more than 10 people during his tenure. An extraordinary success considering the country where he serves in representing Indonesia is known as one of the countries with such a strict legal system.

There are times when violence and the law of a counter country do not need to be reciprocated by showing that we also have the same or more capabilities than that country. If this is the desire, then chaos or small commotion to a big war cannot be avoided. Interpersonal spheres that have conflicts can simply be ignited by emotions that lead to revenge and make relationships break. So imagine if that happens in (at least) 2 countries that just want to make the world a show of greatness. What happens?

In the author's view, this is so great as to underlie the existence of exposure from silent diplomacy. Deeper, the focus of the researcher's attention is on one case, namely Sumartini and Warnah, who have been sentenced since 2009 until finally being released again in 2019. The Indonesian ambassador to Saudi, Agus Maftuh Abegebriel managed to negotiate until finally they were both accused of practicing black magic in the form of magic was freed.

The friendly approach taken by the Great Ambassador was very surprising. Through the "friendship approach", this is like the silent diplomacy carried out by Soeharto during his previous reign and in contrast to secret diplomacy not being publicized at all either in the processor in the result. In quiet diplomacy, what is avoided is during publication, but the final agreement is worth knowing (and celebrating) by the public.

Soeharto took action to normalize diplomatic relations with China by exploring his meeting at the funeral of Emperor Hirohito. Normalization is carried out after all the preparations have matured and domestic resistance has not so affected the process. The existence of silent democracy has fears of irrelevant interventions from outside that can disrupt the overall plan that has been prepared. Convinced by the author that the attempt to liberate the two Indonesian citizens is not the first time carried out by the Indonesian government. Maximum protection of the rights and obligations of Citizens is always carried out. The problem is why at the beginning they were not willing to "release" the two suspects?

This is where the art of persuasion takes a role. How did Ambassador Agus use the approach of singing and poetry with religious leaders. Not in the framework of capturing the heart for personal interests, but for the sake of success in bringing back the daughters of the Indonesian people to their own country. Ambassador Agus has the maximum ability to build credibility and exposure of relevant evidence so that senior Saudi officials (Riyadh) fall in love.

Apart from that, the author also highlights that not everything described in public has meaningful value or importance. Call it Siti Aisyah's freedom from the Court in Malaysia. His release was seen as a form of "petition" to the Malaysian Court. All of this was the result of the collaboration of the assistance team from Indonesia and the Ministry of Foreign Affairs. If the news about the team and maximum support from Indonesia are too much or 
over aired than it should, then don't blame it when silent diplomacy fails to be carried out until good intentions to maintain the nation's good relations become a thumbs up.

The author has his view that the law and human rights which are the pillars of this research have not been fully discussed thoroughly because the communication and diplomacy sides are so dominant. Not without reason. The existence of communication that can reach and cover a variety of sciences, makes it difficult not to be discussed or accidentally become the main topic. In essence, the struggle for diplomacy is not easy and has not yet ended, but continues, merely providing the best service for the sons and daughters of a nation that is having noble interests in a neighboring country.

\section{CONCLUSION AND SUGESTION}

The struggle diplomacy of the death penalty where the Indonesian citizens is located cannot be separated from the elements of communication, politics, and diplomacy in it. The element of power that seemed hollow, apparently still took a role there. The position of who becomes controlled and masters is ultimately confusing.

Call it the one who has power is a country that can provide punishment. This then puts migrant workers who are considered guilty, also Indonesia is considered as a "controlled party" finally it is better to just stay quiet and surrender. Viewed from a different perspective, Indonesia has full power over the country where the migrant workers is ruled because the existence of the migrant workers is a figure that is needed by the state (say Saudi Arabia and Malaysia). The complexity is increasingly felt when it is said that the individual (migrant workers) has the same power as the power of the State. This is in fact because his position is protected and given full rights by law.

In practice, power is not that simple. The law is indeed binding and in a contextual context. But the interesting slices of how the tug between running the law in harmony with human rights is the main PR of every country which reportedly always supports peace on behalf of the Vienna Convention.

The existence of the law requires that to kill someone's life as a consequence of what he/she has done. But it is reminded that humans do not live in such a rigid scope, but also promote the conscience. On this matter, diplomacy then works to be considered right and to be understood by other countries that are colleagues.

Over the anxiety of the author's initial question about How does Indonesia fight for the Human Rights of Indonesian citizens who are sentenced to death in other countries through diplomacy? It was answered so clearly and easily. Indonesia is not just a person, Indonesia is not just a migrant worker and Indonesia is a symbol of unity. When there is confusion over the unfair fate that befell one of its citizens, then all elements of the country will move. The next question, who is the filter and the exact command?

The government is in the hands of a president. The realization of the policy is in the cold hands of a woman who holds the post of Foreign Minister. In his journey, he was not alone but was assisted by one of the men who served as Ambassador in a country that was more or less known to have a long good history (there were also bad memories) with Indonesia. 
Migrant workers who is protected also has the same right to express his opinion or desire for the situation. Since the beginning of the departure of a migrant worker to another country, the average is done in a way that is conscious and full of high imagination. It would be frustrating to turn that wishful thinking into the reality that the land of people is not as beautiful as in fairyland.

This led to research on the final presentation that the success of a country is not only seen from how many enemies it managed to conquer. Furthermore, it is precisely how many countries are friendly with it. Indonesia, which has had sparks of conflict with Malaysia can still make the two Heads of State chat and give each other praise. If it is said to disagree with Saudi Arabia, in fact, Indonesia is still very able to persuade them to follow the rules and refrain from overly interfering in domestic affairs.

Then the question is who is the real enemy of Indonesia? It seems that the question is not appropriate to be given to neighboring countries, rather than the idea of being asked into one's nation. The rejection of human rights violations in other countries continues to be encouraged, while the procurement of capital punishment in the country for both its own and foreign citizens continues to be carried out. This then becomes a paradox and sometimes makes the idea that the Government is unjust in developing this country.

\section{REFERENCE}

Ahmad, Nyarwi. 2012. Manajemen Komunikasi Politik \& Marketing Politik. Pustaka Zaman:Yogyakarta.

Cangara, H. 2016. Komunikasi Politik: Konsep, Teori, dan Praktik. Edisi 5. Penerbit Rajawali Pers:Jakarta.

Dinh, Tranh Van. 1987. Communication and Diplomacy in Changing World. Ablex Pub Corp:Michigan University.

Denzin, N. K, \& Lincoln, Y. S. 1994. Handbook of Qualitative Research. Sage Publications, Inc.: California.

Griffiths, Aaron with Catherine Barnes. 2008. Powers of persuasion. Conciliation Resources:London. Leftwich, Adrian. 2004. What is Politics - The Activity and its Study Polity. Polity Press Ltd:Cambridge.

Littlejohn, Stephen W. dan Foss, Karen A. 2009. Theories of Human Communication. Terjemahan Mohammad Yusuf Hamdan. Penerbit Salemba Humanika:Jakarta.

Lucas, Stephen E. 2012. The Art of Public Speaking. McGraw Hill:New York.

McNair, B. 2003. An Introduction to Political Communication. Routledge London dan New York. Moleong, Lexy J. 2009. Metodologi Penelitian Kualitatif. Penerbit PT Remaja Rosda Karya:Bandung. Mulyana, Deddy. 2007. Ilmu Komunikasi Suatu Pengantar. Penerbit PT Remaja Rosda Karya:Bandung.

Severin, Werner J and James W. Tankard, Jr. 2001. Communication Theories: Origins, Methods and Uses in the Mass Media. Addison Wesley Longman, Inc.: London.

West, Turner \& Lynn H. Turner. 2007. Pengantar Teori Komunikasi, Analisis dan Aplikasi. Buku 2. Salemba Humanika: Jakarta. 
Watson, Adam. 1982. Diplomacy: The Dialogue Between State. Methuen. Ch.1.

\section{United Nations Development Programme (UNDP)}

https://www.antaranews.com/berita/1127264/profil-menlu-retno-marsudi-diplomat-ulungsegudang-prestasi

https://kemlu.go.id/portal/id/read/582/view/menlu-retno-dorong-pembentukan-sistempelayanan-dan-perlindungan-wni-yang-terstandarisasi-dan-terintegrasi

https://beritagar.id/artikel/berita/pemerintah-klaim-selamatkan-ratusan-wni-dari-hukumanmati

http://journalinternationalrelations.blogspot.com/2016/12/kaitandiplomasi-dan-politik-luarnegeri.html

https://www.komnasham.go.id/files/1475231474-uu-nomor-39-tahun-1999-tentang-

\$H9FVDS.pdf https://www.bbc.com/indonesia/indonesia-48053523

https://internasional.kompas.com/read/2019/03/13/12575141/fakta-pembebasan-siti-aisyahdari-jerat-hukuman-mati-di-malaysia?page $=$ all

https://international.sindonews.com/read/1402961/40/hubungan-indonesia-malaysia-lovehate-relationship-1557437394

https://international.sindonews.com/read/1408576/40/5-rencana-aksi-malaysia-pererathubungan-bilateral-dengan-indonesia-1559145405

https://databoks.katadata.co.id/datapublish/2019/04/09/malaysia-masih-menjadi-tujuanutama-para-tenaga-kerja-indonesia

https://kemlu.go.id/kualalumpur/id/pages/bagaimana_menjadi_tenaga_kerja_indonesia/97/ab out-service

https://www.voaindonesia.com/a/menlu-retno-dan-menlu-arab-saudi-bahas-perlindungantki/4625820.html

https://www.beritasatu.com/ekonomi/516035/indonesia-dan-arab-saudi-sepakat-sistem-satukanal-tki 